\title{
The liver, the brain and nitrogen metabolism
}

\author{
Piero Amodio
}

Received: 2 April 2008 / Accepted: 28 October 2008 /

Published online: 24 December 2008

(C) Springer Science + Business Media, LLC 2008

The existence of a relationship between the liver and behavior change has long been recognized.

In the eighteenth century Giovanni Battista Morgagni reported the case of a man with liver cirrhosis who had coma and subsequently died, whose gross brain examination did not show any alteration (Morgagni 1765) (Fig. 1).

A relationship between portal-systemic shunting of blood and behavioral alterations, including coma, was clearly proven in porto-caval shunted dogs (i.e., submitted to Eck fistula) by Hahn et al. (1893) who demonstrated that meat-rich meals could cause 'encephalitis'. Ammonia salts were proven to cause coma in patients with liver cirrhosis in the 30s by van Coulert (Van Caulert et al. 1932) and Sthal (Sthal 1936).

However, it was a further few decades before the works of hepatologists, such as Sherlock (Sherlock et al. 1954; Read and Laidlaw 1967) and Conn (Conn and Lieberthal 1979), and of neurologists, such as Adams (Adams and Foley 1953;Victor et al. 1965) formally identified the syndrome of 'portal-systemic encephalopathy' or, as it is referred to more commonly today, 'hepatic encephalopathy'.

Since 1972 neuroscientists and hepatologists with a common interest in the interaction between hepatic dysfunction, alterations of nitrogen metabolism and brain functioning have been meeting regularly to advance understanding of this complex field. In the first meeting, which took place in Budapest in Hungary, Sir Hans Krebs presented the newly discovered hepatic urea cycle. The key role played by ammonia in the pathogenesis of hepatic encephalopathy was mooted and debated, for many years, in these triennial meetings, before its primacy in the pathophysiology of the syndrome was finally established and agreed. Many of the 'alternative' theories proposed to explain the pathogenesis of hepatic encephalopathy, for example the role of branched chain amino acids, the 'GABA-hypothesis', the role

Piero Amodio is the President of the 13th ISHEN Meeting, Padua, Italy.

\footnotetext{
P. Amodio $(\bowtie)$

Department of Clinical and Experimental Medicine, University of Padua, Via Giustiniani,

2-35128 Padua, Italy

e-mail: piero.amodio@unipd.it
} 


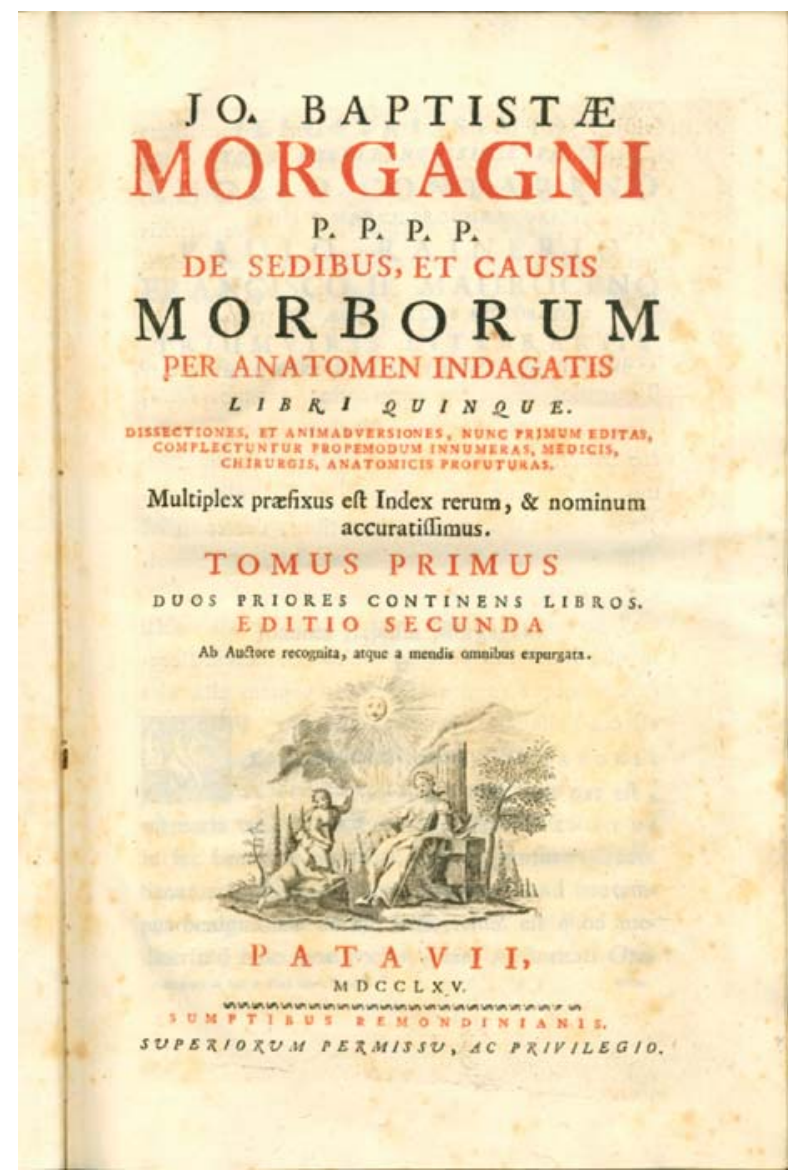

Fig. 1 The Morgagni's Book of Medicine where liver cirrhosis and a possible case of HE are described. (Information kindly provided by M. Norenberg. Book in the Ancient Library of the Faculty of medicine of Padua)

of cerebral oedema and inflammatory cytokines and, more recently, ideas on interorgan ammonia trafficking often had their first airing at these gatherings.

Some clues for a progress in the understanding of this syndrome regard the changes occurring into the brain due to ammonia (Butterworth 2003; Haussinger 2006; Norenberg et al. 2007) and body ammonia trafficking (Olde Damink et al. 2002a, b; Romero-Gomez et al. 2006). In addition, new features of brain-liver interaction are appearing on the horizon and are worthy of consideration: a detrimental influence of HCV virus on cognitive function and wellbeing (Forton et al. 2001), either related to the virus per se or to systemic or brain inflammatory response; the influence of liver transplantation and immunosuppressive agents on the brain (Amodio et al. 2007); the renewed interest for nutrition, microelements deficiency, notably - but not only-thiamine; and the consequences of alcohol misuse (Butterworth 1995; Kalaitzakis et al. 2007).

Treatment for hepatic encephalopathy is still based, somewhat empirically, on our concepts of the pathogenesis of the syndrome and so primarily on methods to 
prevent the production, absorption and elimination of ammonia. Newer treatment approaches are mooted, but progress often frustrating slow, despite the fact that hepatic encephalopathy is one of the most serious consequences of severe liver disease. In fact, $i$ ) HE is the hallmark of acute liver failure (O'Grady et al. 1993); ii) episodes of HE concern about $10 \%$ of patients with compensated cirrhosis and about $40 \%$ of patients with decompensated cirrhosis in a 5 year follow up (D'Amico et al. 1986; Ginés et al. 1987), iii) HE complicates about $20 \%$ of TIPPS procedure greatly reducing the quality of life $i v$ ) $\mathrm{HE}$, even in its minimal expression, is a marker of low survival expectancy (Merkel et al. 1989; Bustamante et al. 1999; Romero-Gomez et al. 2001; Amodio et al. 2001; Stewart et al. 2007).

Progress in determining a 'gold standard' for the diagnosis of this condition represents an extraordinary challenge for instrumental techniques: structural and functional brain imaging, neurophysiology, neuropsychology and psychophysiology. Even basic clinical classification of behavior and motor alterations need to be further focused to detect and properly represent HE.

All these areas have been delineated and debated and have been added to the 'standing agenda' for the meetings.

The long-standing informal relationship between neuroscientists and hepatologists involved in this field was recently formalized by the creation of the International Society for Hepatic Encephalopathy and Nitrogen Metabolism (ISHEN). The first formal meeting of this society, the thirteenth meeting since 1972, was held in Padua, Italy in May 2008 (A. a 2008). This issue of Metabolic Brain Diseases contains some of the invited lectures designed to clarify some of the more important issues in this field.

\section{References}

A. a (2008) 13th International Symposium on Hepatic Encephalopathy and Nitrogen Metabolism. The 13th ISHEN. Liver Int 28:721-752

Adams RD, Foley JM (1953) The neurological disorder associated with liver disease. Res Publ Assm Res Nerv Ment Dis 32:198-237

Amodio P, Del Piccolo F, Petteno E, Mapelli D, Angeli P, Iemmolo R, Muraca M, Musto C, Gerunda G, Rizzo C, Merkel C, Gatta A (2001) Prevalence and prognostic value of quantified electroencephalogram (EEG) alterations in cirrhotic patients. J Hepatol 35:37-45

Amodio P, Biancardi A, Montagnese S, Angeli P, Iannizzi P, Cillo U, D’Amico D, Gatta A (2007) Neurological complications after orthotopic liver transplantation. Dig Liver Dis 39:740-747

Bustamante J, Rimola A, Ventura PJ, Navasa M, Cirera I, Reggiardo V, Rodes J (1999) Prognostic significance of hepatic encephalopathy in patients with cirrhosis. J Hepatol 30:890-895

Butterworth RF (1995) Pathophysiology of alcoholic brain damage: synergistic effects of ethanol, thiamine deficiency and alcoholic liver disease. Metab Brain Dis 10:1-8

Butterworth RF (2003) Pathogenesis of hepatic encephalopathy: update on molecular mechanisms. Indian J Gastroenterol 22(Suppl 2):S11-S16

Conn HO, Lieberthal MM (1979) The hepatic coma syndromes and lactulose. Williams \& Wilkins, Baltimore

D’Amico G, Morabito A, Pagliaro L, Marubini E (1986) Survival and prognostic indicators in compensated and decompensated cirrhosis. Dig Dis Sci 31:468-475

Forton DM, Allsop JM, Forster GR, Thomas HC, Taylor-Robinson SD (2001) Evidence for a cerebral effect of thehepatitis C virus. The Lancet 358:38-39

Ginés P, Quintero E, Arroyo V, Teres J, Bruguera M, Rimola A, Caballería J, Rodés J, Rozman C (1987) Compensated cirrhosis: natural history and prognostic factors. Hepatology 7:122-128 
Hahn M, Massen O, Nencki M, Pavlov I (1893) Die Eck'sche fistel zwischen der unteren hohlvene und der pfortader und ihre folgen fur den organismus. Arch Exp Pathol Pharm 32:161-210

Haussinger D (2006) Low grade cerebral edema and the pathogenesis of hepatic encephalopathy in cirrhosis. Hepatology 43:1187-1190

Kalaitzakis E, Olsson R, Henfridsson P, Hugosson I, Bengtsson M, Jalan R, Bjornsson E (2007) Malnutrition and diabetes mellitus are related to hepatic encephalopathy in patients with liver cirrhosis. Liver Int 27:1194-1201

Merkel C, Bolognesi M, Angeli P, Noventa F, Caregaro L, Sacerdoti D, Gatta A (1989) Prognostic indicators of survival in patients with cirrhosis and esophageal varices, without previous bleeding. Am J Gastroenterol 84:717-722

Morgagni GB (1765) De sedibus et causis morborum per anatomen indagatis libri quinque. Remondinus, Padova

Norenberg MD, Jayakumar AR, Rama Rao KV, Panickar KS (2007) New concepts in the mechanism of ammonia-induced astrocyte swelling. Metab Brain Dis 22:219-234

O’Grady JG, Schalm SW, Williams R (1993) Acute liver failure: redefining the syndromes. Lancet 342:273-275

Olde Damink SW, Deutz NE, Dejong CH, Soeters PB, Jalan R (2002a) Interorgan ammonia metabolism in liver failure. Neurochem Int 41:177-188

Olde Damink SW, Jalan R, Redhead DN, Hayes PC, Deutz NE, Soeters PB (2002b) Interorgan ammonia and amino acid metabolism in metabolically stable patients with cirrhosis and a TIPSS. Hepatology 36:1163-1171

Read AESS, Laidlaw J et al (1967) The neuro-psychiatric syndromes associated with chronic liver disease and an extensive portal-systemic collateral circulation. Q J Med 141:135-150

Romero-Gomez M, Boza F, Garcia-Valdecasas MS, Garcia E, Aguilar-Reina J (2001) Subclinical hepatic encephalopathy predicts the development of overt hepatic encephalopathy. Am J Gastroenterol 96:2718-2723

Romero-Gomez M, Jover M, Diaz-Gomez D, de Teran LC, Rodrigo R, Camacho I, Echevarria M, Felipo V, Bautista JD (2006) Phosphate-activated glutaminase activity is enhanced in brain, intestine and kidneys of rats following portacaval anastomosis. World J Gastroenterol 12:2406-2411

Sherlock S, Summerskill WHJ, White LP, Phear EA (1954) Portal-systemic encephalopathy. Neurological complications of liver disease. The Lancet 453-457. Sept 4,1954

Stewart CA, Malinchoc M, Kim WR, Kamath PS (2007) Hepatic encephalopathy as a predictor of survival in patients with end-stage liver disease. Liver Transpl 13:1366-1371

Sthal J (1936) Studies of the blood ammonia in liver disease. Ann Intern Med 58:1-24

Van Caulert C, Deviller C, Halff M (1932) Troubles provoques par l'ingestion de sels ammoniacaux chez l'homme atteint de cirrhose de Laennec. Comptes Rendus Soc Biol 111:739-740

Victor M, Adams RD, Cole M (1965) The acquired (non Wilsonian) type of chronic hepatocerebral degeneration. Medicine 44:345-396 